\title{
Upper Berriasian ammonites from the Taraises Formation of Cuencamé de Ceniceros section, Durango State, Northern Mexico
}

Celestina González-Arreola, Ricardo Barragán, Miguel Company, Josep A. Moreno-Bedmar, Rubén Gruz-Vázquez

Celestina González-Arreola Ricardo Barragán

ricardor@geologia.unam.mx

Josep A. Moreno-Bedmar

Departamento de Paleontología, Instituto de Geología, Universidad Nacional Autónoma de México, Ciudad Universitaria, Delegación Coyoacán, 04510, CDMX, Mexico.

\section{Miguel Company}

Departamento de Estratigrafía y Paleontología, Facultad de Ciencias, Universidad de Granada, Av. Fuentenueva s.n. 18002, Granada, Spain.

\section{Rubén Gruz-Vázquez}

Facultad de Estudios Superiores Iztacala, Universidad Nacional Autónoma de México, Av. de los Barrios 1, Los Reyes Iztacala, Tlalnepantla de Baz, 54090, Estado de México, Mexico.
BOL. SOC. GEOL. MEX 2017

VOL. 69 NO. 2

P. $465-477$

\begin{abstract}
We present evidence of late Berriasian sedimentation which records the presence of Spiticeras correardi, whose stratigraphic range is not well established. Located at Cuencamé de Ceniceros, Durango State, northern Mexico, a section belonging to the Taraises Formation is here presented to show our results. Furthermore, the sampled ammmonite assemblage - herein constituted by Fauriella cf. boissieri, Berriasella cf. calisto, Spiticeras correardi, and Kilianiceras praegratianopolitense - is attributed to the upper Berriasian standard Mediterranean ammonite Zone Fauriella boissieri. It is worth noting that $B$. cf. calisto has strong biostratigraphic significance, due to the fact that it is restricted to the upper part of the aforementioned Fauriella boissieri Zone (Tirnovella alpillensis and Thurmanniceras otopeta subzones).
\end{abstract}

Keywords: Ammonoids, upper Berriasian, Taraises Formation, Mexico, Fauriella boissieri Zone, marine transgression.

\section{RESUMEN}

Presentamos evidencia de sedimentación del Berriasiano tardío que registra contenido de Spiticeras correardi, cuyo rango estratigráfico hasta ahora no se encuentra bien establecido. Nuestros resultados se señalan en una sección estratigráfica correspondiente a la Formación Taraises, ubicada en Cuencamé de Ceniceros, en el Estado de Durango, norte de México. La asociación de ammonoideos en la sección - formada por Fauriella cf. boissie-

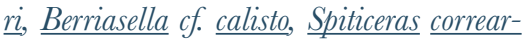
di, y Kilianiceras praegratianopolitense- se atribuye aqui a la Zona Fauriella boissieri, del Berriasiano superior del estándar Mediterráneo. Vale la pena señalar que la especie B. cf. calisto tiene un fuerte significado bioestratigráfico, pues se encuentra restringida a la parte superior de la mencionada Zona Fauriella boissieri (Subzonas Tirnovella alpillensis y Thurmanniceras otopeta).

Palabras clave: Ammonoideos, Berriasiano superior, Formación Taraises, México, Zona Fauriella boissieri, transgresión marina. 


\section{Introduction}

The Berriasian, considered the formal lowest Cretaceous stage since the "Symposium on the Lower Cretaceous" held in Lyon in 1963 (Barbier and Thieuloy, 1965), has called the attention of different researches for its peculiar stratigraphy and ammonites record.

In Mexico, the studies on the Berriasian initiated with the contribution of Felix (1891), who reported the presence of the genus Subthurmannia from Cerro de la Virgen, nearby Tlaxiaco in Oaxaca State, southern Mexico. Afterwards, among the few works that reported Berriasian ammonoids in Mexico, are the pioneering contributions of Burckhardt (1906, 1910, 1912, 1919 and 1930). This author collected Berriasian ammonoids in the locality "Cerro del Aguajito", San Pedro del Gallo, Durango State (1910) that he afterwards described in detail in 1912. He compared those ammonoids with coeval forms from south Europe and the Andean region. Those materials are deposited in the Colección Paleontológica Nacional (National Paleontological Collection), held by the Instituto de Geología of the Universidad Nacional Autónoma de México, and have served as a comparative reference to constrain the late Berriasian from the base of the Taraises Formation in the work presented herein. The same author (Burckhardt, 1930), integrated all information available at that time, regarding ammonites from the Berriasian and other Mesozoic stages. Posteriorly, Imlay (1938) describes the Taraises Formation from the west of Parras town in the State of Coahuila; this author reconsidered the information published by Burckhardt (1912), referring a Berriasian-Valanginian age for the unit. Afterwards, Imlay (1944) reported Berriasian ammonites from Tamaulipas State, northeast Mexico, highlighting the presence of the genera Berriasella, Spiticeras, Neocosmoceras and Hemispiticeras. Cantú-Chapa (1967) made a study of facies of Berriasian age from the Lower Tamaulipas Formation of Mazatepec, Puebla in central Mexico, containing abundant specimens of the ammonites Subthurmannia mazatepense, Subthurmannia dominguense, Subthurmannia sp., Groebericeras poblanense, Berriasella aff. zacatecana and Spiticeras sp. Later, the same author (Cantú-Chapa, 1976) studied ammonites of early Berriasian age such as Neolissoceras semisulcata Burckhardt and Subthurmannia sp., and from the upper Berriasian such as Berriasella neohispanica Burckhardt and Spiticeras (Spiticeras) sp.; recovered from the well Bejuco 6, in Veracruz State. Contreras-Montero et al. (1991) displayed the late Berriasian ammonite Berriasella (Picteticeras) picteti (Jacob) from "Cerro del Panteón" locality in Durango State.

Since then, few studies have been performed in Mexico regarding Berriasian ammonoids, standing out a recent contribution by Zell et al. (2015), on which the Berriasian-Valanginian boundary is defined in southern Mexico by means of ammonites and calpionellids.

In this work, we compare the currently studied ammonites with the south-European Berriasian ammonite record. The material was collected by systematic bed-by-bed sampling in a section located near the vicinity of the town Cuencamé de Ceniceros, Durango State, northern Mexico. Despite the small number of the herein studied specimens, these ammonites allow us to record the presence of the upper Berriasian in the lower part of the Taraises Formation. This lithostratigraphic unit was defined by Imlay (1936) in the type locality of "El Cañón de Taraises", Coahuila State; where he also characterized its fossil record allowing to assign its age range from the Valanginian to the early Hauterivian. Later, the same author (Imlay, 1938) reassigned such age range of the Taraises Formation expanding its lower limit into the Berriasian. Here we characterize upper Berriasian ammonoids to accumulate updated data about the taxonomical and biostratigraphical significance of this fossil group for Mexico. Our data and future reports will allow the establishment of similarities and differences of the Mexican Berriasian ammonites with the standard Mediterranean ammonite zonation of Reboulet et al. (2014), a scheme that 
we use here as the best available option, due to the lack of an American ammonite biozonation for the Berriasian stage.

\section{Geological setting}

The Taraises Formation has excellent exposures in northern Mexico. Imlay (1936) defined this formation as a limestone and marly limestone that contains abundant Valanginian and Hauterivian fauna. Nowadays, it is well-known that the lower limit of the unit extends into the Berriasian. The same author divided the formation into two members. The lower member is constituted by dark to grey limestone beds separated by thin marly intervals. It is more resistant to erosion than the upper member and can be clearly observed in the field, conspicuously overlaying the sandstones and Jurassic black shales from the La Casita Formation. Imlay (1936) describes the upper member as dark to grey thin-bedded limestones with intercalated marly intervals.

Regionally, during the Late Jurassic, a marine transgression started, and continued on the Early Cretaceous, covering most of northeast Mexico (Burckhardt, 1930; Imlay, 1938; Morán-Zenteno, 1994). Such event gave way, throughout the entire Berriasian-Barremian interval, to deposition of a heterogeneous sequence composed of various formations that reflects a spectrum from littoral and continental into basinal facies. The ammonite-bearing argillaceous limestones of the Taraises Formation (Imlay, 1936) were deposited during the Berriasian-Hauterivian interval in the southeast sector of the Sabinas Gulf. The section herein studied represents a portion of the late Berriasian sedimentation within this important Mesozoic paleogeographic element of northeast Mexico on a local extent. It is located to the east of the small city of Cuencamé de Ceniceros, Durango State (Figure 1). It is bounded by the parallel $24^{\circ} 43^{\prime}$ $30^{\prime \prime}$ and $24^{\circ} 44^{\prime} 30^{\prime \prime}$ north latitude and the meridian $103^{\circ} 31^{\prime}$ and $103^{\circ} 32^{\prime}$ west longitude according to the Cuencamé sheet map (Enciso de la Vega,
1968). The thickness of the studied section (Figure 2) is $21.85 \mathrm{~m}$ of an irregular alternation of thin-bedded limestones and thicker marls which can be, unambiguously, attributed to the lower member of the Taraises Formation. We named this section as CU-7 due to successive fieldwork campaigns in the area. The particular lithological features of the lower member of the formation in our study area are more similar to those from the "El Cerro del Aguajito", San Pedro del Gallo, Durango State studied by Burckhardt (1912); compared to the type area of the formation in Coahuila State. Burckhardt (1912) described the fossiliferous limestones of the Taraises Formation that overlay the La Casita Formation. Those materials correspond to thin-bedded brownish to yellowish limestones because of the presence of iron oxide. Despite the thinness and limited exposure of the fossiliferous limestones, we obtained a quite representative collection of Berriasian ammonites.

\section{Systematic paleontology}

Seven samples, mostly composed by poorly preserved phragmocones and an inner whorl were studied herein, among which five are figured in this work (Figure 3). Material is deposited at the Colección Paleontológica Nacional (National Paleontological Collection), held by the Instituto de Geología of the Universidad Nacional Autónoma de México, under catalogue numbers IGM 4903 through IGM 4907 as indicated in the explanation of Figure 3.

A detailed analysis of the ammonites allows their taxonomic ascription - mostly following the systematic arrangement proposed by Wright et al. (1996) and Klein (2005) - . For a better taxonomical characterization of specimens, some measurements of their morphological features are given (in millimeters). Those with asterisk are approximate. The measurements abbreviations are D: maximum diameter; Wh: whorl height; Ww: whorl width; and U: umbilicus diameter. For biostratigraphical purposes we used the standard Med- 


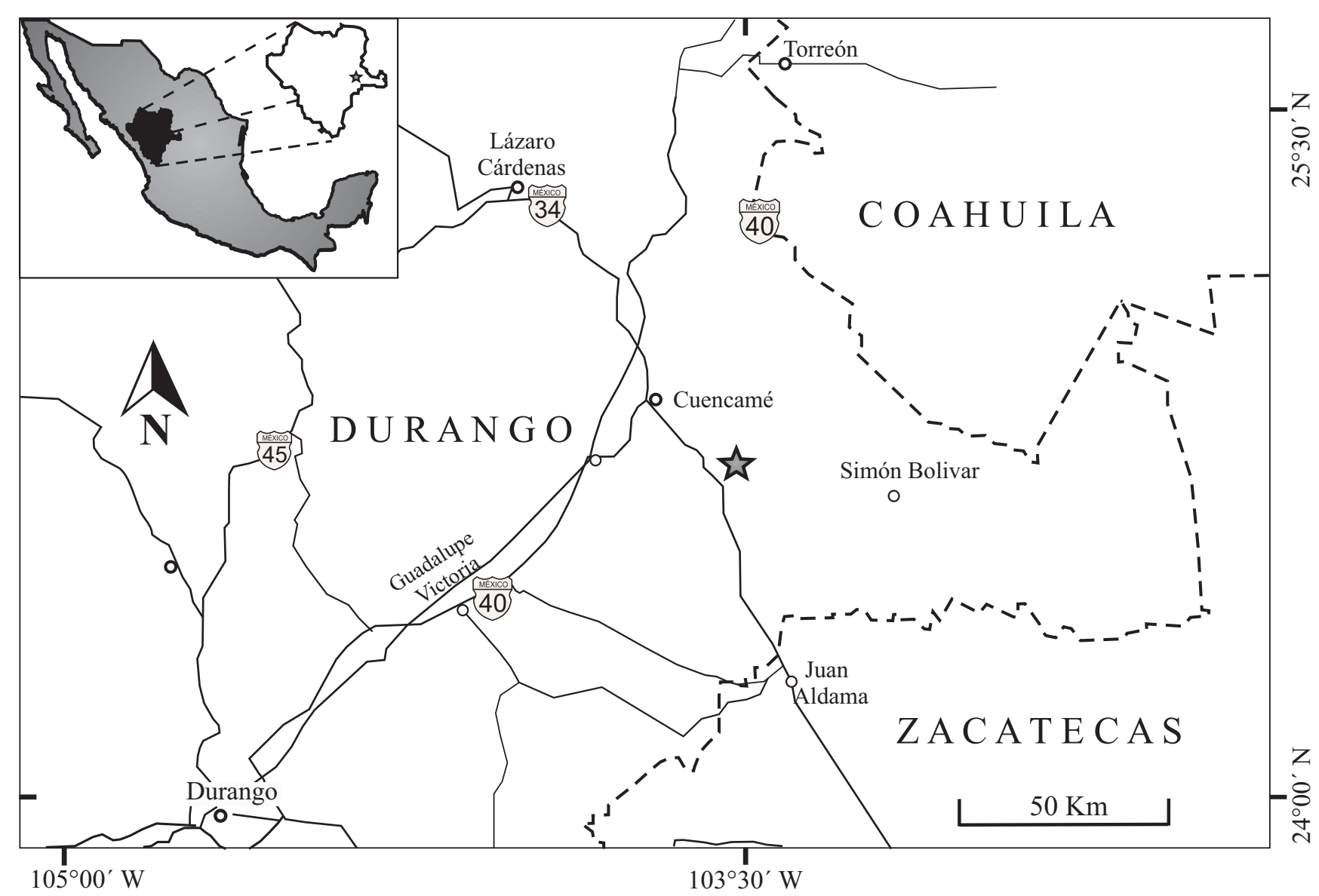

Figure 1 Geographic location of the studied section in Cuencamé de Ceniceros, Durango State, Mexico. The fossiliferous locality is marked with a star. Dashed lines indicate State boundaries, while continuous lines represent major highways.

iterranean ammonite zonation of Reboulet et al. (2014). The range of ammonite taxa is illustrated in Figure 2. In this regard, it is worth to note that, contrary to Wright et al. (1996), who regarded the genus Fauriella as being a synonym of Subthurmannia, in this work we follow the points of view of Le Hégarat (1973) and Nikolov (1982), who considered both genera to be valid. In consequence, we use the specific name Fauriella boissieri, instead of Subthurmannia boissieri, to characterize the uppermost zone of the Berriasian in the standard Mediterranean ammonite zonation.

Suborder Ammonitina Hyatt, 1889

Superfamily Perisphinctoidea Steinmann, 1890

Family Neocomitidae Salfeld, 1921

Subfamily Berriasellinae Spath, 1922
Genus Fauriella Nikolov, 1966

Type species. Berriasella gallica Mazenot, 1939

Fauriella cf. boissieri (Pictet, 1867)

Figure $3 \mathrm{D}$

1867 Ammonites boissieri Pictet, p. 79, pl. 15,

figs. 1-3.

1993 Fauriella boissieri (Pictet) - Matsumoto and

Skwarko, p. 414, figs. 3, 4, 19A-D.

2005 Fauriella boissieri (Pictet) - Klein, p. 259 (cum syn.).

2007 Fauriella boissieri (Pictet) - Arkadiev, p. 188,

pl. 1, figs. 1-3.

2008 Fauriella boissieri (Pictet) - Arkadiev et al., p. 413, pl. 3, figs. $6,7$. 


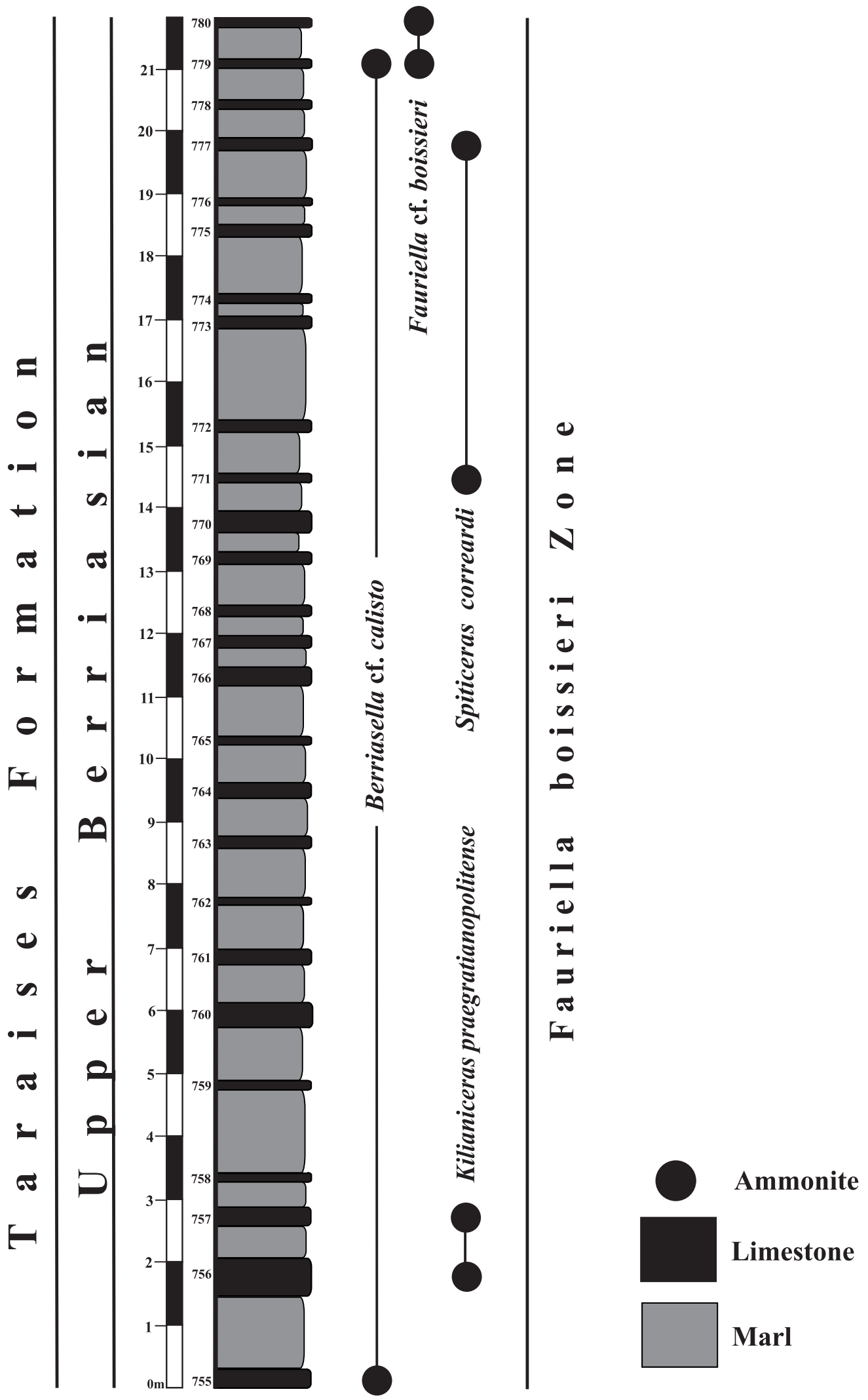


2010 Fauriella boissieri (Pictet) - Főzy et al., p. 531, fig. $4 a, b$.

2013 Fauriella boissieri (Pictet) - Bujtor et al., p. 286, figs. $5 \mathrm{j}-\mathrm{k}$.

2013 Fauriella boissieri (Pictet) - Krische et al., p. 40, fig. 13A.

2014 Fauriella boissieri (Pictet) - Kenjo, p. 34,

pl. 11, figs. 1-6, Pl. 12, figs. 1-4, pl. 13, fig. 1.

Material. Two incomplete specimens with only the last whorl preserved (Table 1). CU7-779a (illustrated in Figure 3) and CU7-780.

Description. Evolute shell with a compressed whorl section and flanks nearly flat. Umbilical region wide and deep, rounded umbilical shoulders. The section is compressed. The ornamentation is constituted by strong ribs, rectiradiate to slightly flexuous, that arise isolated or in pairs from a small umbilical tubercle. The ribs bifurcate in the upper third of the flank, the space between these is equal to the thickness. All ribs have an adoral projection in the upper third of the flank and cross the ventral region without interruption.

Discussion. The characteristic ornamentation of Fauriella boissieri is very similar to the specimen illustrated in this work. Preservation of herein studied ammonoids, particularly in their last whorl, permits a direct comparison with the specimens illustrated by Le Hégarat (1973, Pl. 21, figs. 1-3; Pl. 48, fig. 1) and Company (1987, Pl. 4, fig. 7; Pl. 18, fig. 6). The only differences are that, in the Mexican specimens, the tubercles, from which the ribs arise, are smaller and the ribs interspaces are bigger. The specimens showed by Matsumoto and Skwarko (1993, figs. 19 A, D) and by Wippich (2001, Pl. 13, fig. 1), are closer to our specimens in their more rigid costulation, their interspaces dimensions, and in the fact that their ribs cross the ventral region without interruption. The species Fauriella boissieri is characterized by possessing

Table 1. Dimensions of specimens of Fauriella cf. boissieri (Pictet, 1867).

\begin{tabular}{|c|c|c|c|c|}
\hline Specimen & $\mathbf{D}(\mathbf{m m})$ & $\mathbf{W h}(\mathbf{m m})$ & $\mathbf{W w}(\mathbf{m m})$ & $\mathbf{U}(\mathbf{m m})$ \\
\hline CU7-779a & $88.5^{*}$ & 34.9 & 20.1 & 29.1 \\
\hline CU7-780 & 65 & 30.5 & --- & 28.4 \\
\hline
\end{tabular}

a smooth siphonal band; however, this cannot be observed in our specimens. Nonetheless, Company (1987) mentioned that this siphonal band disappears during ontogenetic development.

Distribution. The range of Fauriella boissieri is upper Berriasian (Fauriella boissieri Zone) to lowermost Valanginian. This species has been reported in France (Mazenot, 1939; Le Hégarat, 1973), Spain (Tavera, 1985; Company, 1987), Austria (Krische et al., 2013; Bujtor et al., 2013), Crimea (Arkadiev, 2007; Arkadiev et al., 2008), Hungary (Főzy et al., 2010), Bulgaria (Nikolov, 1966), Italy (Faraoni et al., 1997), the Alps (Immel, 1987), Morocco (Wippich, 2001), Papua New Guinea (Matsumoto and Skwarko, 1993) and Madagascar (Collignon, 1962).

Genus Berriasella Uhlig, 1905

Type species. Ammonites privasensis Pictet, 1867

$$
\text { Berriasella cf. calisto (d’Orbigny, 1850) }
$$

Figure $3 \mathrm{H}$

1850 Ammonites calisto d'Orbigny, p. 551, Pl. 213,

figs. 1, 2.

2005 Berriasella (Berriasella) calisto (d’Orbigny) -

Klein, p. 166 (cum syn).

2008 Berriasella calisto (d'Orbigny) - Arkadiev et al.,

p. 416, Pl. 4, fig. 2.

2013 Berriasella (Berriasella) calisto (d'Orbigny) -

Bujtor et al., p. 283, fig. 5A.

2014 Berriasella calisto (d'Orbigny) - Kenjo, p. 31,

Pl. 9, figs. 5, 6, Pl. 10, figs. 1-10.

2015 Berriasella cf. calisto (d’Orbigny) - Boorová et al., p. 116, fig. 9C.

Material. Two fragmented and poorly preserved specimens. GU7-755 (illustrated in Figure 3) and GU7- 779b.

Description. Shell with flattened flanks (Wh: CU-755=31*mm; Wh: CU7-779b=13 mm). Ventral region and umbilicus cannot be observed. Ornamentation consists on flexuous ribs that arise on the umbilical region. Some ribs bifurcate at the last third of the flank where they also become projected forward. 
Discussion. When compared with the holotype, and other typical representatives of the species, the studied specimens display a very similar shell structure and ribbing design. Nevertheless, our specimens show a distinctly higher proportion of non-bifurcate ribs.

Distribution. This species has strong biostratigraphic significance because it is restricted to the upper Berriasian, in particular to the upper part of the Fauriella boissieri Zone (Tirnovella alpillensis and Thurmanniceras otopeta subzones). The taxon has been reported from France (Mazenot, 1939; Le Hégarat, 1973), Spain (Company, 1982; Tavera, 1985), Bulgaria (Nikolov, 1982), Poland (Pszczólkowski and Myczynski, 2004), Crimea (Arkadiev et al., 2008), Austria (Vašíček et al., 1999; Bujtor et al., 2013; Boorová et al., 2015), Hungary (Főzy et al., 2010), Madagascar (Collignon, 1962), Mexico (Burckhardt, 1910, 1919) and Argentina (Leanza and Wiedmann, 1989).

Family Olcostephanidae Haug, 1910

Subfamily Spiticeratinae Spath, 1924

Genus Kilianiceras, Djanélidzé, 1922

Type species. Stephanoceras damesi Steuer, 1897

Kilianiceras praegratianopolitense Djanélidzé, 1922

Figure $3 \mathrm{~A}-\mathrm{C}, \mathrm{E}-\mathrm{F}$

\section{? 1922 Spiticeras (Kilianiceras) damesiforme n. sp. -}

Djanélidzé, p. 119, Pl. 9, figs. la, b.

1922 Spiticeras (Kilianiceras) praegratianopolitense n. sp.

- Djanélidzé, p.122, Pl. 8, figs. 1a, b.

1987 Spiticeras (Kilianiceras) praegratianopolitense

Djanélidzé - Immel, p. 69, Pl. 3, fig. 4.

Material. Two quite well-preserved specimens (Table 2), one of them slightly crushed and the second with only the inner whorls visible. CU7756 and CU7-757, both illustrated in Figure 3.

Table 2. Dimensions of specimens of Kilianiceras praegratianopolitense Djanélidzé, 1922

\begin{tabular}{|c|c|c|c|c|}
\hline Specimen & $\mathbf{D}(\mathbf{m m})$ & $\mathbf{W h}(\mathbf{m m})$ & $\mathbf{W w}(\mathbf{m m})$ & $\mathbf{U}(\mathbf{m m})$ \\
\hline CU7-756 & 35.4 & 11.5 & 13.5 & 19.1 \\
\hline CU7-757 & 82.7 & 23.5 & 16.6 & 37.5 \\
\hline
\end{tabular}

Description. Evolute shell with a compressed whorl section. Flattened flanks with an umbilical wall relatively high and inclined. Umbilicus wide and staggered. The cross section is higher than wide. Ornamentation in the inner whorls is constituted by simple, rectiradiate and strong ribs that arise from twenty-five small tubercles on the umbilical wall. A second line of tubercles appears on the ribs at mid-flank, from which two strong prosiradiate ribs bifurcate to later cross the ventral region, showing an attenuated siphonal band. The spaces between the ribs are twice the thickness of the ribs. In addition, in one specimen two strong and relatively deep constrictions can be observed cutting the ribs obliquely. In the last whorl the ornamentation is characterized by twenty-two compressed radial tubercles in the lower third of the flank, where the main ribs bifurcate or trifurcate in approximately twenty six prorsiradiate ribs. Between each bifurcation there are two residual ribs. All the ribs are projected showing a chevron-like pattern on the ventral region. Additionally, one accessory rib can be observed.

Discussion. The shape of the tubercles, and the number of ribs and their bifurcations, are the key elements to identify this species. Although our specimens are smaller than those illustrated by Djanélidzé (1922, p. 122, Pl. 8 fig. 1 a-b) and by Immel (1987, p.69, Pl. 3, fig. 4), we can assign them with certainty to this taxon.

Distribution. Kilianiceras praegratianopolitense is restricted to the upper Berriasian and the lowermost Valanginian. The species has been reported from the Berriasian of France (Djanélidzé, 1922), Spain (Allemann et al., 1975) and the early Valanginian of Austrian Alps (Immel, 1987).

Genus Spiticeras Uhlig, 1903

Type species. Ammonites spitiensis Blanford, 1864

Spiticeras correardi Djanélidzé, 1922

Figure $3 \mathrm{G}$

1922 Spiticeras correardi Kil. in litt. - Djanélidzé, p. 160, Pl. 18, figs. 3 a-c. 
2005 Spiticeras correardi Djanélidzé - Klein, p. 52 (cum syn.).

2015 Spiticeras (Spiticeras) cf. correardi Djanélidzé Boorová et al. p. 108, fig. 10B.

Material. Two poorly preserved specimens (Table 3). CU7-771 (illustrated in Figure 3) and CU7-777.

Description. Small depressed involute shell with rounded flanks. Umbilical shoulder rounded with an inclined wall. Small shallow umbilicus. Inner whorls cannot be observed. Ornamentation constituted by thin prorsiradiate ribs that appear in pairs from twelve small peri-umbilical tubercles. Later, the ribs bifurcate at mid-flank crossing without interruption the ventral region. The specimens show two strong constrictions parallel to the ribs or inclined forward, one of them in the middle part of the last whorl and the other close to the aperture.

Discussion. The herein studied specimens show a similar ribbing pattern compared with the lectotype of Djanélidzé (1922, pl. 18, figs. a-c). However, it has to be mentioned that our specimens only record the inner whorls of this species. Mexican specimens are also very similar in the rib pattern to the exemplar showed by Boorová et al. (2015, fig. 10B) but with fewer tubercles. The ornamentation pattern can be compared to that of Spiticeras polytroptychum Djanélidzé (1922, pl. 7, figs. 2 a-b; pl. 18, figs. $4 \mathrm{a}-\mathrm{b})$, differing only in that $S$. polytroptychum has a more robust ornamentation.

Distribution. The stratigraphic range of Spiticeras correardi is not well established (Boorová et al., 2015) but seems to span from the upper Berriasian to the lower Valanginian. The Mexican specimens described here belong to the upper Berriasian Fauriella boissieri Zone. Spiticeras correardi has been recorded from the Berriasian of France (Djanélid- zé, 1922), and the early Valanginian of Bulgaria (Nikolov, 1960) and Austria (Boorová et al., 2015).

\section{Discussion}

Based on ammonites herein described, section CU-7 from Cuencamé de Ceniceros, Durango State, correlates to the base of the lower member of the Taraises Formation, and can be attributed to a record of sedimentation of the latest Berriasian. Even though its stratigraphic record can span into the lowermost Valanginian, Fauriella boissieri is considered the index species of the latest Berriasian Boissieri Zone for the Mediterranean Domain and southeast France (Company, 1987; Le Hégarat, 1973). The record of $F$. cf. boissieri in this work is restricted to the top of the studied section. However, it is coincident with the last stratigraphic record of Berriasella cf. calisto; recovered from both, the base and the top of the studied section. $B$. cf. calisto has a strong biostratigraphic significance for our interpretation, since it is restricted to the upper Berriasian, in particular to the upper part of the Fauriella boissieri Zone (Tirnovella alpillensis and Thurmanniceras otopeta subzones) of the standard Mediterranean ammonite zonation (Le Hégarat, 1973; Tavera, 1985; Company, 1987; Arkadiev and Bogdanova, 2004; Bujtor et al., 2013; Boorová et al., 2015). Thus, the stratigraphic section, subject of this study, is indicative of sedimentation of the latest Berriasian Boissieri Zone, and records the presence of other ammonites such as Spiticeras correardi, species whose stratigraphic range is until now not well established according to Boorová et al. (2015).

\section{Conclusions}

The base of the lower member of the Taraises Formation in a section near Cuencamé de Ceniceros (Durango State, Mexico) has provided an ammonite fauna composed of Berriasella cf. calisto,
Table 3. Dimensions of specimens of Spiticeras correardi Djanélidzé, 1922.

\begin{tabular}{|c|c|c|c|c|}
\hline Specimen & $\mathbf{D}(\mathbf{m m})$ & $\mathbf{W h}(\mathbf{m m})$ & $\mathbf{W w}(\mathbf{m m})$ & $\mathbf{U}(\mathbf{m m})$ \\
\hline CU7-771 & 17.7 & 7.5 & --- & 9.2 \\
\hline CU7-777 & 15.1 & 7.2 & --- & 8.6 \\
\hline
\end{tabular}



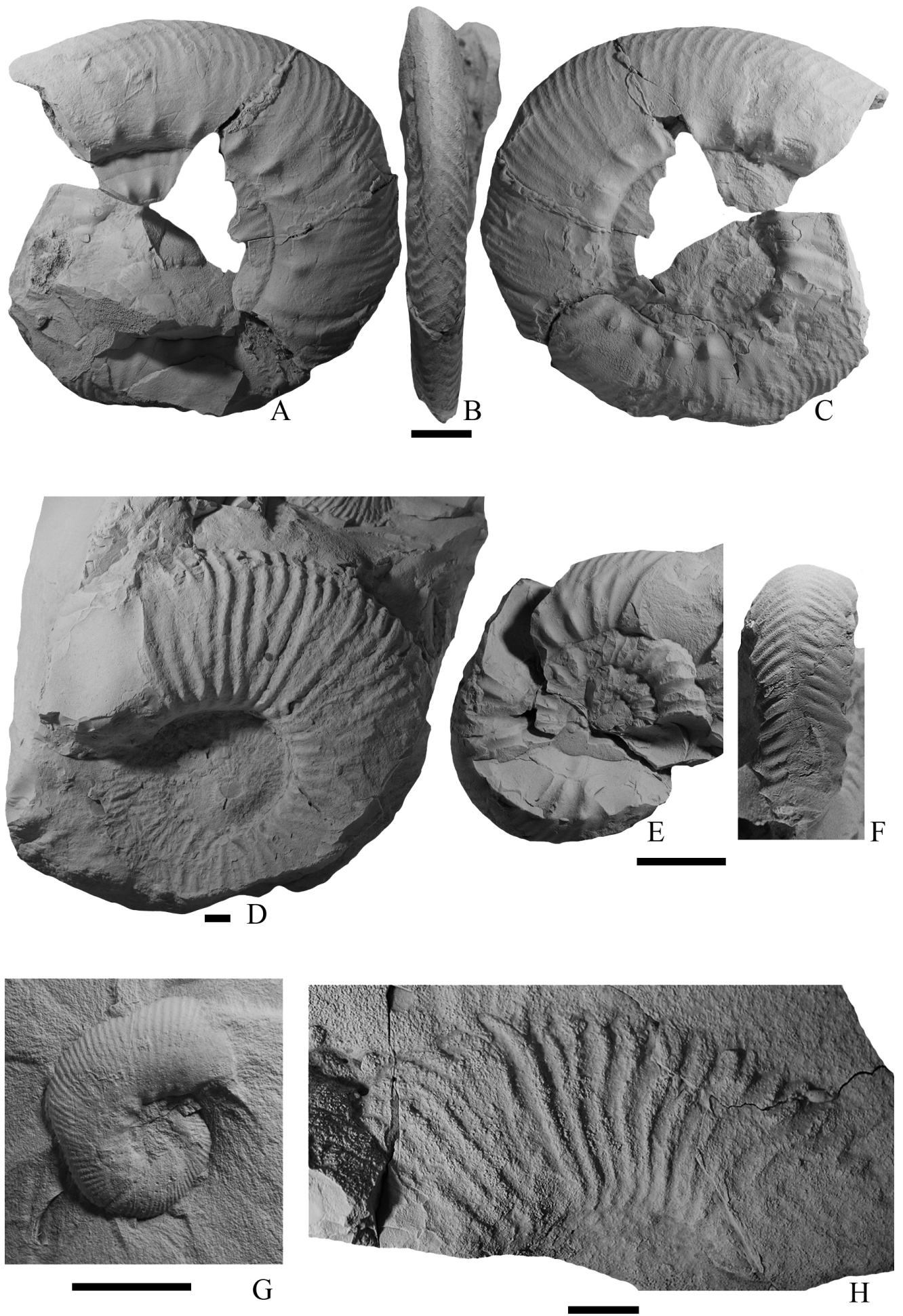

Figure 3 Ammonites from Cuencamé de Ceniceros, Durango, Mexico, attributed to the upper Berriasian standard Mediterranean ammonite Zone Fauriella boissieri. A-C (CU7-757) IGM-4903, E-F (CU7-756) IGM-4904 Kilianiceras praegratianopolitense Djanélizdé, 1922, A, left side; B, ventral side; C, right side; E, right side and the umbilical region; F, ventral side. D (CU7-779a) IGM-4905 Fauriella cf. boissieri (Pictet, 1867). G (CU7-771) IGM-4906 Spiticeras correardi Djanélizdé, 1922. H (CU7-755) IGM-4907 Berriasella cf. calisto (d'Orbigny, 1850). In all cases scale bar equals $1 \mathrm{~cm}$. 
Fauriella cf. boissieri, Spiticeras correardi, and Kilianiceras praegratianopolitense. Despite some minor morphological differences, this ammonite assemblage shows strong affinities with those reported from the uppermost Berriasian in the Mediterranean region. Furthermore, it allows the assignation of the studied stratigraphic interval to the upper part of the Fauriella boissieri Zone (Tirnovella alpillensis and Thurmanniceras otopeta Subzones) of the standard Mediterranean ammonite zonation (Reboulet et al., 2014).

This work constitutes the first report for Mexico of the upper Berriasian species Kilianiceras praegratianopolitense, Spiticeras correardi and Fauriella cf. boissieri.

\section{Acknowledgements}

The authors wish to express their gratitude to Dr. José M. Tavera for his constructed comments that helped to improve the manuscript. Dr. Federico Olóriz Sáez and Dra. Ana Bertha Villaseñor Martínez, are thanked for their help in section measuring and sampling of paleontological material. We also thank Dr. Jesús Alvarado Ortega, head of the Museum "Carmen Perrillat" of the Instituto de Geología of the Universidad Nacional Autónoma de México, and MSc. Violeta Amparo Romero Mayén, technician of the Colección Paleontológica Nacional, for their help during the use of the museum facilities. We are very grateful for the helpful corrections and suggestions made by Dr. Patrick Zell and one anonymous reviewer. This research is a contribution to Project IN 108516 of the Program UNAM-DGAPA-PAPIIT.

\section{References}

Allemann, F., Grün, W., Wiedmann, J., 1975, The Berriasian of Caravaca (Prov. of Murcia) in the Subbetic Zone of Spain and its importance for defining this stage and the Jurassic-Cretaceous boundary, in Colloque sur la limite Jurassique-Crétacé: Lyon, Mémoires du Bureau de Recherches Géologiques et Minières, 86, 14-22.

Arkadiev, V.V., 2007, Ammonite Fauriella boissieri (Pictet), the Index Species of the Berriasian Upper Zone from the Crimea Mountains: Stratigraphy and Geological Correlation, 15, 185-192.

Arkadiev, V.V., Bogdanova, T.N., 2004, Genus Berriasella (Ammonoidea) and Ammonoid Zonation in the Berriasian of the Crimea Mountains: Stratigraphy and Geological Correlation, 2(4), 367-379.

Arkadiev, V.V., Bogdanova, T.N., Lobacheva, S.V., Kalacheva, E.D., Sey, I.I., 2008, Berriasian Stage of the Crimea Mountains: Zonal Subdivision and Correlation: Stratigraphy and Geological Correlation, 16, 400-422.

Barbier, R., Thieuloy, J.P., 1965, Étage Berriasien, in Colloque sur le Crétacé inférieur, 1963: Lyon, Mémoires du Bureau de Recherches Géologiques et Minières, 34, 69-77.

Blanford, H.F., 1864, On Dr. Gerard's collection of fossils from the Spiti valley, in the Asiatic Society's museum: Journal of the Asiatic Society of Bengal, 32, 124-138.

Boorová, D., Skupien, P., Vašíček, Z., Lobitzer, H., 2015, Biostratigraphy of the Lower Cretaceous Schrambach Formation on the classical locality of Schrambachgraben (Northern Calcareous Alps, Salzburg Area): Bulletin of Geosciences, 90, 89-131.

Bujtor, L., Krische, O., Gawlick, H.J., 2013, Late Berriasian ammonite assemblage and biostratigraphy of the Leube quarry near Salzburg (Northern Calcareous Alps, Austria): Neues Jahrbuch für Geologie und Paläontologie Abhandlungen, 267, 273-295. Burckhardt, C., 1906, La faune jurassique de Mazapil avec un appendice sur les fossiles du Crétacique inférieur: Boletín del Instituto Geológico de México, 23, 1-216. 
Burckhardt, C., 1910, Estudio Geológico de la región de San Pedro del Gallo Durango: Parergones del Instituto Geológico de México, 2, 302-357.

Burckhardt, C., 1912, Faunes jurassiques et crétaciques de San Pedro del Gallo: Boletín del Instituto Geológico de México, 29, 1-264.

Burckhardt, C., 1919, Faunas jurásicas de Symon (Zacatecas) y cretácicas de Zumpango del Río (Guerrero): Boletín del Instituto Geológico de México, 33, 1-135.

Burckhardt, C., 1930, Etude synthétique sur le Mésozoïque mexicain: Mémoires de la Société Paléontologique Suisse, 2(49-50), 1-280.

Cantú-Chapa, A., 1967, El límite JurásicoCretácico en Mazatepec, Puebla (México), Instituto Mexicano del Petróleo, Sección Geología, Monografía 1(1), 3-24.

Cantú-Chapa, A., 1976, El Contacto JurásicoCretácico, la Estratigrafía del Neocomiano, el Hiato Hauteriviano Superior-Eoceno Inferior y las amonitas del Pozo Bejuco 6 (Centro-Este de México): Boletín de la Sociedad Geológica Mexicana, 37, 60-69.

Company, M., 1987, Los ammonites del Valanginiense del sector oriental de las Cordilleras Béticas (SE de España): España, Universidad de Granada, Tesis Doctoral, $294 \mathrm{p}$.

Collignon, M., 1962, Atlas des fossiles caractéristiques de Madagascar (Ammonites). Fascicule VIII (Berriasien, Valanginien, Hauterivien, Barrémien), Service Géologique Tananarive, $96 \mathrm{p}$.

Contreras-Montero, B., Gómez Luna, M.E., Martínez Cortes, A., González Casildo, V., 1991, Catálogo de las amonitas de México, Parte II Cretácico Inferior (Berriasiano, Valanginiano y Hauteriviano) CAO-5508: México, Instituto Mexicano del Petróleo, Subdirección de Tecnología de Exploración.

Djanélidzé, A., 1922, Les Spiticeras du SudEst de la France: Mémoires pour servir á l'Explication de la Carte géologique détaillée de France, 255 p.

Enciso de la Vega, S., 1968, Resumen de la Geología de la Hoja Cuencamé. Estado de Durango: Universidad Nacional Autónoma de México, Instituto de Geología, Carta Geológica de México, Hoja Guencamé 13R-1 (7), escala 1:100000, 1 mapa.

Faraoni, P., Flore, D., Pallini, G., Pezzoni, N., 1997, Valanginian and early Hauterivian ammonite successions in the Mt Catria group (Central Apennines) and in the Lessini Mts (Southern Alps), Italy: Paleopelagos, 7, 59-100.

Felix, J., 1891, Versteinerungen aus der mexicanischen Jura- und Kreide-Formation: Palaeontographica, 37, 140-194.

Főzy, I., Janssen, N.M.M., Price, G.D., Knauer, J., Pálfy, J., 2010, Integrated isotope and biostratigraphy of a Lower Cretaceous section from the Bakony Mountains (Transdanubian Range, Hungary): A new Tethyan record of the Weissert event: Cretaceous Research, 31, 525-545.

Haug, E., 1910, Periode Crétacé, in Haug, E. (Ed.), Traité de Géologie, vol. 2, Les Périodes géologiques, fascicule 2: Paris, Colin 1153-1396.

Hyatt, A., 1889, Genesis of the Arietitidae: Smithsonian contributions to Knowledge, 673, 1-238.

Imlay, R.W., 1936, Evolution of the Coahuila peninsula, Mexico. Part IV. Geology of the western part of the Sierra de Parras: Bulletin of the Geological Society of America, 47, 1091-1152.

Imlay, R.W., 1938, Ammonites of the Taraises Formation of Northern Mexico: Bulletin of the Geological Society of America, 49, 539-602.

Imlay, R.W., 1944, Cretaceous formations of Central America and Mexico: Bulletin of the American Association of Petroleum Geologists, 28(8), 1077-1195.

Immel, H., 1987, Die Kreideammoniten der Nördlichen Kalkalpen: Zitteliana, 15, 3-163. 
Kenjo, S., 2014, Biostratigraphie intégrée à nannofossiles calcaires et ammonoïdes: développement et implications pour la définition et la valorisation des stratotypes d'unité et de limite. L'exemple des étages Berriasien et Valanginien et de leur limite ( 140 Millions d'années): Lyon, France, Université Glaude Bernard, Thèse Doctorat, $226 \mathrm{p}$.

Klein, J., 2005, Lower Cretaceous Ammonites I. Perisphinctaceae 1. Himalayitidae, Olcostephanidae, Holcodiscidae, Neocomitidae, Oosterellidae, in Riegraf, W. (ed.) Fossilium Catalogus I: Animalia pars 139, Leiden, The Netherlands, Backhuys, $484 \mathrm{p}$.

Krische, O., Bujtor, L., Gawlick, H., 2013, Calpionellid and ammonite biostratigraphy of uppermost Jurassic to Lower Cretaceous sedimentary rocks from the Leube Quarry (Northern Calcareous Alps, Salzburg, Austria): Austrian Journal of Earth Sciences, 106(1), 26-45.

Leanza, H.A., Wiedmann, J., 1989, Nuevos ammonites del Berriasiano/Valanginiano (Cretácico inferior) de Neuquén, Argentina, in Wiedmann, J. (ed.), Cretaceous of the western Tethys, Proceedings of the $3^{\text {rd }}$ International Cretaceous Symposium, 1987: Tübingen, Germany, 793-810.

Le Hégarat, G., 1973, Le Berriasien du Sud-Est de la France: Documents des Laboratoires de Géologie de la Faculté des Sciences de Lyon, 43(1), 1-308.

Matsumoto, T., Skwarko, S.K., 1993, Cretaceous ammonites from south-central Papua New Guinea: Journal of Australian Geology and Geophysics, 14(4), 411-433.

Mazenot, G., 1939, Les Palaehoplitidae tithoniques et berriasiens du Sud-Est de la France: Mémoires de la Société Géologique de France (nouvelle série), 41, 1-303.

Morán-Zenteno, D., 1994, Geology of the Mexican Republic: Studies in Geology, American
Association of Petroleum Geologists, 39, $1-160$

Nikolov, T., 1960, La faune d'ammonites dans le Valanginien du Prébalkan oriental: Travaux sur la Géologie de Bulgarie, Série Paléontologie, 2, 143-261. (In Bulgarian with French résumé).

Nikolov, T., 1966, New genera and subgenera of ammonites of family Berriasellidae: Comptes rendus de l'Académie Bulgare des Sciences, 19, 639-642.

Nikolov, T., 1982, Les Ammonites de la famille Berriasellidae Spath, 1922, Tithonique supérieur-Berriasen, Sofia, Bulgaria: Editions Académie Bulgare des Sciences, 251 p.

Orbigny, A., d', 1850, Paléontologie française. Description zoologique et géologique de tous animaux mollusques et rayonnés fossiles de France, comprenant leur application à la reconnaissance des couches. Terrains oolitiques our jurassiques. Vol. I, Cephalopodes, 521-632.

Pictet, F.J., 1867, Etudes paléontologiques sur la faune a Terebratula diphyoides de Berrias (Ardèche): Melanges paléontologiques Genève, 1(2), 43-131.

Pszczólkowski, A., Myczynski, R., 2004, Ammonite supported microfossil and nannoconid stratigraphy of the TithonianHauterivian limestones in selected sections of the Branisko Succession, Pieniny Klippen Belt (Poland): Studia Geologica Polonica, 123, 133-197.

Reboulet, S., Szives, O., Aguirre-Urreta, B., Barragán, R., Company, M., Idakieva, V., Ivanov, M., Kakabadze, M.V., MorenoBedmar, J.A., Sandoval, J., Baraboshkin, E.J., Çağlar M.K., Főzy, I., González-Arreola, C., Kenjo, S., Lukeneder, A., Raisossadat, S.N., Rawson, P.F., Tavera, J.M., 2014, Report on the $5^{\text {th }}$ International Meeting of the IUGS Lower Cretaceous Ammonite Working Group, the Kilian Group (Ankara, Turkey, 31st August 2013): Cretaceous Research, 50, 126-137. 
Salfeld, H., 1921, Kiel-und Furchenbildung auf der Schalenaußenseite der Ammonoideen in ihrer Bedeutung für die Systematik und Festlegung von Biozonen. Centralblatt für Mineralogie: Geologie und Paleontologie, 343-347.

Spath, L.F., 1922, On Cretaceous Ammonoidea from Angola, collected by Professor J.W. Gregory, D. Sc., F. R. S: Transactions of the Royal Society of Edinburgh, 53, 91-160.

Spath, L.F., 1924, On the ammonites of the Speeton Clay and the subdivisions of the Neocomian: Geological Magazine, 61, 73-89.

Steinmann, G., 1890, Elemente der Paleontologie, in Steinmann, G., Döderlein, L. (eds.). Wilhelm Engelmann, Leipzig, 848 p.

Steuer, A., 1897, Argentinische Jura-Ablagerungen. Ein Beitrag zur Kenntnis er Geologie und Paläontologie der argentinischen Anden: Palaeontologische Abhandlungen (Neue Folge Band, 3 ) 7, 129-222.

Tavera, J.M., 1985, Los ammonites del Titónico superior-Berriasense de la Zona Subbética (Cordilleras Béticas): España, Universidad de Granada, PhD Thesis, 381 p.

Uhlig, V., 1903, The fauna of the Spiti Shales. Memoirs of the Geological Survey of India: Palaeontologia Indica, Series 15, Himalayan fossils, 4, 1-132.
Uhlig, V., 1905, Einige Bemerkungen über die Ammonitengattung Hoplites Neumayr. Sitzungsberichte der Kaiserlichen Akademie der Wissenschaften in Wien: Matematischnaturwissenschaftichen Klasse, 1 (114), 591-636.

Vašíček, Z., Reháková, D., Faupl, P., 1999, Zur Biostratigraphie der Schrambachschichten der Oisbergmulde bei Hollenstein a. d. Ybbs (Lunzer Decke, Kalkalpen, Niederösterreich): Abhandlungen Der Geologischen Bundesanstalt (Wien), 56(2), 626-650.

Wippich, M.G.E., 2001, Die tiefe UnterKreide (Berrias bis Unter-Hauterive) im südwestmarokkanischen Becken: Ammonitenfauna, Bio- und Squenzstratigraphie, Bochum, Germany, Ruhr-Universität Bochum, PhD Thesis, 142 p.

Wright, C.W., Calloman, J.H., Howarth, M.K., 1996, Cretaceous Ammonoidea. Treatise on Invertebrate Paleontology, Part L Mollusca 4 Revised: The Geological Society of America and the University of Kansas, Boulder \& Laurence, 362 p.

Zell, P., Stinnesbeck, W., Beckmann, S., Adatte, T., Hering, F., 2015, The BerriasianValanginian (Early Cretaceous) boundary transition at Santa Catarina Ticuá, Oaxaca state, southern Mexico: Ammonites, bivalves, calpionellids and their paleobiogeographic significance: Journal of South American Earth Sciences, 62, 33-57.

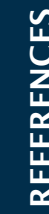

